\title{
Effect of glass hybridization and staking sequence on mechanical behaviour of interply coir-glass hybrid laminate
}

\author{
S JAYABAL*, U NATARAJAN and S SATHIYAMURTHY ${ }^{\dagger}$ \\ Department of Mechanical Engineering, A.C. College of Engineering and Technology, Karaikudi 630 004, India \\ ${ }^{\dagger}$ Department of Mechanical Engineering, Dhaanish Ahmed College of Engineering, Chennai 601 301, India
}

MS received 18 July 2010; revised 24 October 2010

\begin{abstract}
The interest in fibre-reinforced polymer composites is growing rapidly due to its high performance in terms of mechanical properties, significant processing advantages, excellent chemical resistance, low cost, and low density. The development of composite materials based on the reinforcement of two or more fibre types in a matrix leads to the production of hybrid composites. In the present work, woven coir-glass hybrid polyester composites were developed and their mechanical properties were evaluated for different stacking sequences. Scanning electron micrographs of fractured surfaces were used for a qualitative evaluation of interfacial properties of woven coir-glass hybrid polyester composites. These results indicated that coir-glass hybrid composites offered the merits of both natural and synthetic fibres.
\end{abstract}

Keywords. Coir fibre; glass fibre; polyester resin; hybrid laminate; mechanical properties.

\section{Introduction}

Natural fibres exhibit many advantageous properties as reinforcement in fibre-reinforced composites. They are lowdensity materials, yielding relatively light weight composites with specific properties. In an effort to develop a superior, but economical composite, natural fibres can be combined with synthetic fibres in the same matrix material to take the best advantage of both. It is also possible to combine different kinds of fibres to form either an interply or an intraply hybrid laminate. An interply hybrid laminate consists of different kinds of fibres in different laminas, whereas an intraply hybrid laminate consists of two or more different kinds of fibres interspersed in the same lamina (Mallick 1993). Noorunnisa Khanam et al (2010) investigated the tensile, flexural and compressive properties of coir-silk fibre-reinforced composites, and Venkata Subba Reddy et al (2010) evaluated the tensile properties of glass and bamboo fibre-reinforced polyester hybrid composites. The importance for the development of hybrid composites was discussed in their works. Jarukumjorn and Suppakarn (2009) investigated the effect of glass fibre hybridization on the physical properties of sisal-polypropylene composites. In their study, polypropylene grafted with maleic anhydride (PP-g-MA) was used as a compatibilizer to enhance the compatibility between the fibres and polypropylene. Sabeel Ahmed and Vijayarangan (2008) studied the effect of stacking sequence on the mechanical properties of woven jutecoir hybrid composites and they suggested that the glass

\footnotetext{
*Author for correspondence (jayabalsubbaian@ rediffmail.com)
}

plies at the extreme end has good mechanical strength. Geethamma et al (2005) investigated the mechanical properties of short coir-rubber composites and suggested the economical composites using coir fibres. Monteiro et al (2008) evaluated structural characteristics and mechanical properties of coir fibre/polyester composites. They analysed variation of the flexural strength with the mass fraction of coir fibres and molding pressure. Mishra et al (2003) studied the effect of glass fibres addition on tensile, flexural and izod impact strength of pine apple leaf fibre (PALF) and sisal fibre-reinforced polyester composites. Pavithran et al (1991) evaluated the enhancement in the properties of coir-polyester composites by incorporating glass as intimate mix with coir. Harish et al (2009) investigated the mechanical properties of randomly oriented coir composites mixed with epoxy resin and suggested for low load applications. The present study focuses on the evaluation of mechanical properties of interply woven coir-glass hybrid polyester laminate of different stacking sequences.

\section{Experimental}

\subsection{Selection of high modulus fibre}

The plain woven roving fabric of $610 \pm 10 \% \mathrm{~g} / \mathrm{m}^{2}$ (manufactured as per BS:3749 and IS:11273), supplied by Goa Glass Fibres Ltd, Goa, India was used in this work. It had $61 \pm 5 \%$ fibres in warp direction and $55 \pm 5 \%$ fibres in weft direction per $10 \mathrm{~mm}$ length. It was selected by comparing the density and strand width values with that of woven coir roving. 
Table 1. Tensile, flexural and impact properties of 2-layered hybrid composites.

\begin{tabular}{|c|c|c|c|c|c|c|c|c|}
\hline Sl. no. & Sample nos & $\begin{array}{l}\text { Stacking } \\
\text { sequence }\end{array}$ & $\begin{array}{c}\text { Tensile } \\
\text { strength } \\
(\mathrm{MPa})\end{array}$ & $\begin{array}{c}\text { Average } \\
\text { tensile } \\
\text { strength }(\mathrm{MPa})\end{array}$ & $\begin{array}{c}\text { Flexural } \\
\text { strength } \\
(\mathrm{MPa})\end{array}$ & $\begin{array}{c}\text { Average } \\
\text { flexural } \\
\text { strength }(\mathrm{MPa})\end{array}$ & $\begin{array}{c}\text { Impact } \\
\text { strength } \\
\left(\mathrm{kJ} / \mathrm{m}^{2}\right)\end{array}$ & $\begin{array}{c}\text { Average } \\
\text { impact } \\
\text { strength }\left(\mathrm{kJ} / \mathrm{m}^{2}\right)\end{array}$ \\
\hline 1 & $\mathrm{~S} 1$ & \multirow[t]{5}{*}{ GC } & 33 & \multirow[t]{5}{*}{34} & 67 & \multirow[t]{5}{*}{64} & 80 & \multirow[t]{5}{*}{89} \\
\hline 2 & $\mathrm{~S} 2$ & & 38 & & 64 & & 72 & \\
\hline 3 & S3 & & 33 & & 63 & & 97 & \\
\hline 4 & $\mathrm{~S} 4$ & & 34 & & 60 & & 81 & \\
\hline 5 & S5 & & 32 & & 64 & & 117 & \\
\hline 6 & $\mathrm{~S} 1$ & \multirow[t]{5}{*}{ CG } & 39 & \multirow[t]{5}{*}{34} & 67 & \multirow[t]{5}{*}{64} & 69 & \multirow[t]{5}{*}{87} \\
\hline 7 & S2 & & 30 & & 63 & & 113 & \\
\hline 8 & S3 & & 34 & & 63 & & 84 & \\
\hline 9 & S4 & & 32 & & 62 & & 79 & \\
\hline 10 & S5 & & 30 & & 63 & & 91 & \\
\hline
\end{tabular}

Table 2. Tensile, flexural and impact properties of 3-layered hybrid composites.

\begin{tabular}{|c|c|c|c|c|c|c|c|c|}
\hline Sl. no. & $\begin{array}{c}\text { Sample } \\
\text { nos }\end{array}$ & $\begin{array}{l}\text { Stacking } \\
\text { sequence }\end{array}$ & $\begin{array}{c}\text { Tensile } \\
\text { strength } \\
(\mathrm{MPa})\end{array}$ & $\begin{array}{c}\text { Average } \\
\text { tensile } \\
\text { strength (MPa) }\end{array}$ & $\begin{array}{c}\text { Flexural } \\
\text { strength } \\
(\mathrm{MPa})\end{array}$ & $\begin{array}{c}\text { Average } \\
\text { flexural } \\
\text { strength }(\mathrm{MPa})\end{array}$ & $\begin{array}{l}\text { Impact } \\
\text { strength } \\
\left(\mathrm{kJ} / \mathrm{m}^{2}\right)\end{array}$ & $\begin{array}{c}\text { Average } \\
\text { impact } \\
\text { strength }\left(\mathrm{kJ} / \mathrm{m}^{2}\right)\end{array}$ \\
\hline 1 & S1 & \multirow[t]{5}{*}{ GGC } & 49 & \multirow[t]{5}{*}{51} & 80 & \multirow[t]{5}{*}{77} & 138 & \multirow[t]{5}{*}{144} \\
\hline 2 & $\mathrm{~S} 2$ & & 63 & & 71 & & 156 & \\
\hline 3 & S3 & & 53 & & 81 & & 136 & \\
\hline 4 & S4 & & 65 & & 78 & & 137 & \\
\hline 5 & S5 & & 23 & & 76 & & 151 & \\
\hline 6 & S1 & \multirow[t]{5}{*}{ GCG } & 47 & \multirow[t]{5}{*}{47} & 63 & \multirow[t]{5}{*}{65} & 78 & \multirow[t]{5}{*}{101} \\
\hline 7 & $\mathrm{~S} 2$ & & 51 & & 71 & & 78 & \\
\hline 8 & S3 & & 53 & & 60 & & 92 & \\
\hline 9 & $\mathrm{~S} 4$ & & 34 & & 65 & & 166 & \\
\hline 10 & S5 & & 51 & & 66 & & 89 & \\
\hline 11 & $\mathrm{~S} 1$ & \multirow[t]{5}{*}{ CGG } & 39 & \multirow[t]{5}{*}{52} & 71 & \multirow[t]{5}{*}{71} & 127 & \multirow[t]{5}{*}{140} \\
\hline 12 & $\mathrm{~S} 2$ & & 53 & & 76 & & 147 & \\
\hline 13 & S3 & & 53 & & 72 & & 138 & \\
\hline 14 & S4 & & 65 & & 70 & & 137 & \\
\hline 15 & S5 & & 50 & & 65 & & 153 & \\
\hline
\end{tabular}

\subsection{Selection of low modulus fibre}

The low stiffness of coir fibres (Young's modulus of 5$10 \mathrm{GPa}$ ) offered the selection for hybridization with glass fibres. Woven coir fabric having a count of $20 \pm 5 \%$ fibres in warp direction and $20 \pm 5 \%$ in weft direction per $10 \mathrm{~mm}$ length was prepared. The diameter of the coir fibre was $0.260 \mathrm{~mm}$ and the weight of the fabric used was $\sim 1220 \mathrm{~g} / \mathrm{m}^{2}$.

\subsection{Selection of resin matrix}

From the list of terephthalic, isophthalic and orthophthalic unsaturated polyester resin types, the orthophthalic type was selected because of its availability, low weight and good compatibility with E-glass fibres. The resin system consisted of unsaturated orthophthalic polyester (specific

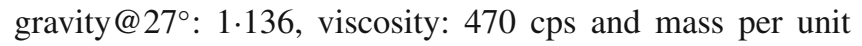

area: 449.96 gsm), MEKP catalyst and Cobalt Octoate accelerator supplied by Sri Vinayaka Enterprises, Chennai, India, was used. The resin properties such as specific gravity and viscosity were tested as per IS:6746:1994 and mass was tested as per ISO 3374 test methods at OCV Reinforcements Manufacturing Ltd, Thimmapur, India.

\subsection{Laminate fabrication}

Hybrid laminates of woven coir and glass mat were prepared by simple hand lay-up process in a mould at laboratory temperature. Poly vinyl acetate release agent was applied to the surfaces before the mould. Woven coir and woven glass fabrics were pre-impregnated with the matrix material consisting of unsaturated polyester, accelerator and catalyst in the

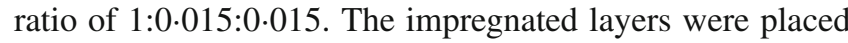
one over the other in the mould $(36 \times 36 \mathrm{~cm})$ and pressed heavily for $1 \mathrm{~h}$ before removal. After $1 \mathrm{~h}$, the laminate was 
Table 3. Elongation, tensile modulus and flexural modulus of 2-layered hybrid composites.

\begin{tabular}{|c|c|c|c|c|c|c|c|c|}
\hline S1. no. & $\begin{array}{c}\text { Sample } \\
\text { nos }\end{array}$ & $\begin{array}{l}\text { Stacking } \\
\text { sequence }\end{array}$ & $\begin{array}{c}\text { Elongation } \\
\text { at break }(\%)\end{array}$ & $\begin{array}{c}\text { Average } \\
\text { elongation } \\
\text { at break }(\%)\end{array}$ & $\begin{array}{c}\text { Tensile } \\
\text { modulus } \\
(\mathrm{MPa})\end{array}$ & $\begin{array}{c}\text { Average } \\
\text { tensile } \\
\text { modulus (MPa) }\end{array}$ & $\begin{array}{l}\text { Flexural } \\
\text { modulus } \\
(\mathrm{MPa})\end{array}$ & $\begin{array}{c}\text { Average } \\
\text { flexural } \\
\text { modulus (MPa) }\end{array}$ \\
\hline 1 & S1 & GC & 8 & 8 & 964 & 1147 & 2057 & 1998 \\
\hline 2 & S2 & & 9 & & 1186 & & 2030 & \\
\hline 3 & S3 & & 8 & & 1065 & & 2034 & \\
\hline 4 & S4 & & 8 & & 1132 & & 1879 & \\
\hline 5 & S5 & & 7 & & 1388 & & 1990 & \\
\hline 6 & S1 & $\mathrm{CG}$ & 9 & 8 & 1064 & 1139 & 2036 & 1990 \\
\hline 7 & S2 & & 8 & & 1187 & & 2028 & \\
\hline 8 & S3 & & 8 & & 1063 & & 2044 & \\
\hline 9 & S4 & & 8 & & 1112 & & 1859 & \\
\hline 10 & S5 & & 7 & & 1268 & & 1986 & \\
\hline
\end{tabular}

Table 4. Elongation, tensile modulus and flexural modulus of 3-layered hybrid composites.

\begin{tabular}{|c|c|c|c|c|c|c|c|c|}
\hline Sl. no. & $\begin{array}{c}\text { Sample } \\
\text { nos }\end{array}$ & $\begin{array}{l}\text { Stacking } \\
\text { sequence }\end{array}$ & $\begin{array}{c}\text { Elongation } \\
\text { at break (\%) }\end{array}$ & $\begin{array}{c}\text { Average } \\
\text { elongation } \\
\text { at break }(\%)\end{array}$ & $\begin{array}{c}\text { Tensile } \\
\text { modulus } \\
(\mathrm{MPa})\end{array}$ & $\begin{array}{c}\text { Average } \\
\text { tensile } \\
\text { modulus (MPa) }\end{array}$ & $\begin{array}{l}\text { Flexural } \\
\text { modulus } \\
(\mathrm{MPa})\end{array}$ & $\begin{array}{c}\text { Average } \\
\text { flexural } \\
\text { modulus (MPa) }\end{array}$ \\
\hline 1 & S1 & GGC & 10 & 10 & 1351 & 1349 & 2463 & 2358 \\
\hline 2 & S2 & & 11 & & 1475 & & 2256 & \\
\hline 3 & S3 & & 10 & & 1327 & & 2384 & \\
\hline 4 & S4 & & 11 & & 1538 & & 2345 & \\
\hline 5 & S5 & & 8 & & 1055 & & 2346 & \\
\hline 6 & S1 & GCG & 10 & 9 & 1329 & 1453 & 1876 & 2881 \\
\hline 7 & S2 & & 10 & & 1366 & & 2873 & \\
\hline 8 & S3 & & 9 & & 1587 & & 3104 & \\
\hline 9 & S4 & & 6 & & 1368 & & 3399 & \\
\hline 10 & S5 & & 8 & & 1617 & & 3156 & \\
\hline 11 & S1 & CGG & 9 & 10 & 1251 & 1373 & 2235 & 2361 \\
\hline 12 & S2 & & 10 & & 1483 & & 2335 & \\
\hline 13 & S3 & & 11 & & 1334 & & 2235 & \\
\hline 14 & S4 & & 9 & & 1437 & & 2457 & \\
\hline 15 & S5 & & 10 & & 1358 & & 2546 & \\
\hline
\end{tabular}

removed from the mould and cured at room temperature for $24 \mathrm{~h}$. The same procedure was followed to prepare different types of hybrid laminates as per the stacking sequence.

\section{Mechanical testing}

\subsection{Tension testing}

Specimens for tension test were carefully cut from the laminate and shaped to the accurate size using emery paper. Tests were conducted using Shimadzu make testing machine (model: AG-IS $50 \mathrm{KN}$, capacity: 5T, and accuracy: 0.2\%) at a cross head speed of $5 \mathrm{~mm} / \mathrm{min}$ as per ASTM D638. Five identical specimens numbered S1, S2, S3, S4 and S5 were tested and average result derived. The tested mechanical property values for 2-layer and 3-layer laminates are given in tables 1 and 2, respectively.

\subsection{Flexural testing}

The flexural test specimen dimension is $127 \times 12.7 \times 3 \mathrm{~mm}$. Flexural test was conducted as per ASTM D 790 using Instron machine (Model no: 3382) with Series IX software and load cell of $10 \mathrm{kN}$ at $2.8 \mathrm{~mm} / \mathrm{min}$ rate of loading. The modulus values for 2-layer and 3-layer laminates are given in tables 3 and 4, respectively. In the 2-layered hybrid composites, coir is one layer and woven glass is another. During flexural testing, the coir/glass plies were differentiated as 
glass-coir (GC) or coir-glass (CG) by the application of load on them.

\subsection{Impact testing}

The impact strength of the samples was measured using an Izod impact test machine as per ASTM D256 standards. The test specimen was supported as a vertical cantilever beam and broken by a single swing of a pendulum using ATS FAAR Impact tester (Model no. 16.1; capacity up to 25 joules). For each case, a total of five specimens were tested and all the tests were carried out at $27^{\circ} \mathrm{C}$. Low velocity instrumented impact tests were carried out on composite specimens. The pendulum impact testing machine ascertains the notch impact strength of the material by shattering the Vnotched specimen with a pendulum hammer, measuring the spent energy, and relating it to the cross section of the specimen. The standard specimen size for ASTM D 256 is $65 \times$ $12.5 \times 3 \mathrm{~mm}$ and the depth under the notch is $10.2 \mathrm{~mm}$.

\section{Results and discussion}

\subsection{Tension testing}

The 3-layer glass-coir hybrid composites exhibited average tensile strength values of $52 \mathrm{MPa}$. The average tensile strength of 2-layer woven coir/polyester composites was found to be $34 \mathrm{MPa}$. The increase of tensile strength and modulus values in 3-layer hybrid composite is due to the addition of one more layer of glass fibres. The increased stacking sequence of glass mats increases the mechanical properties (Mallick 1993). The tensile, flexural and impact strength values for different stacking sequences are shown in figures 1, 2 and 3, respectively. The stress-strain curve of 2-layered coir-glass composites during tensile loading is shown in figure 4.

\subsection{Flexural testing}

The point of deviation from linearity is the indication of failure initiation due to development of crack on the tension side. The elongation at break, tensile modulus and flexural modulus are shown in figures 5, 6 and 7, respectively.

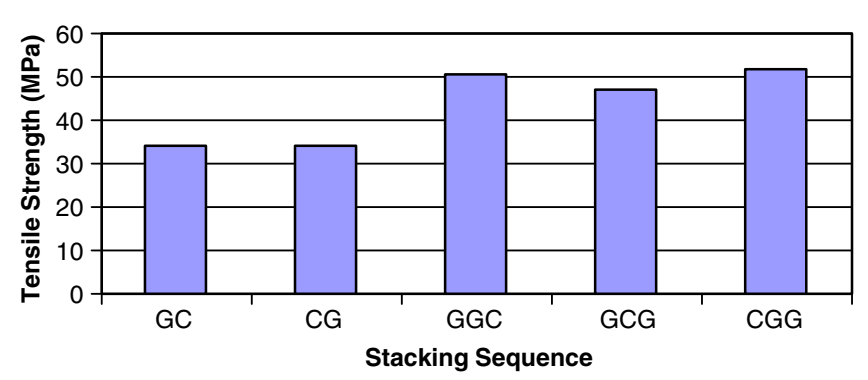

Figure 1. Tensile strength of laminates.

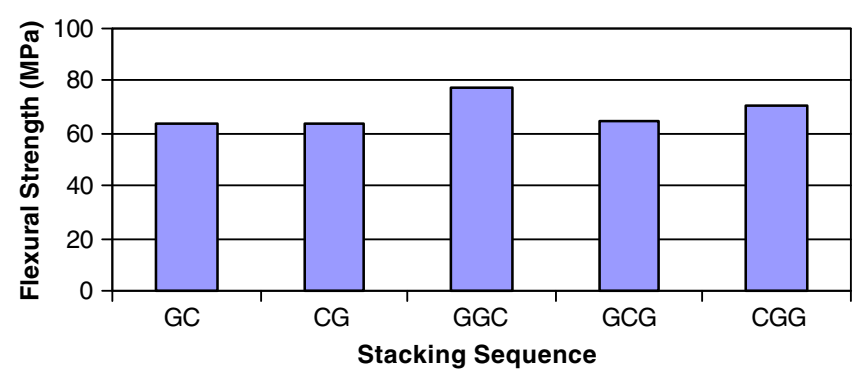

Figure 2. Flexural strength of laminates.

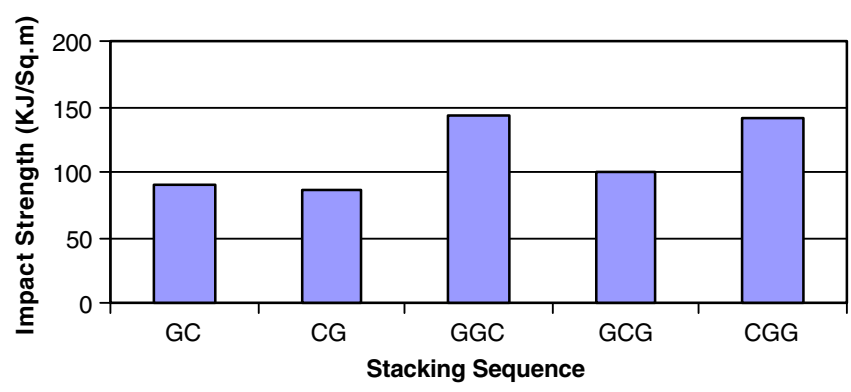

Figure 3. Impact strength of laminates.

The 2-layered coir-glass hybrid laminate exhibited the average value of flexural strength to be $64 \mathrm{MPa}$, whereas the 3layered coir-glass hybrid laminate exhibited $77 \mathrm{MPa}$. The stacking sequence of specimens CCG and GGC had two layers of woven glass and one layer of woven coir mat. But their mechanical properties were slightly different because of testing direction.

During the mechanical test of CGG specimen, the coir surface was subjected to load, whereas in GGC specimen the glass surface was subjected to load. The failure rate is extended in GGC specimen because of two layers of glass mats and their intermingling with polyester resin.

\subsection{Impact testing}

The 3-layer glass-coir hybrid composites exhibited average impact strength values of $144 \mathrm{~kJ} / \mathrm{m}^{2}$. The average impact strength of 2-layer glass-coir hybrid composites was found to be $89 \mathrm{~kJ} / \mathrm{m}^{2}$. The natural fibre coir has good impact strength which is improved by the effect of glass hybridization. The two-layer woven glass mat and single-layer woven coir mat at back opposes the striking force better than woven coir mat and two layer woven glass mat at back. The specimen GGC exhibited higher impact strength than the specimen CGG.

\subsection{SEM analysis of fractured surfaces}

The SEM analyses of fractured surfaces after the mechanical tests are shown in figures 8-11. The matrix crack- 


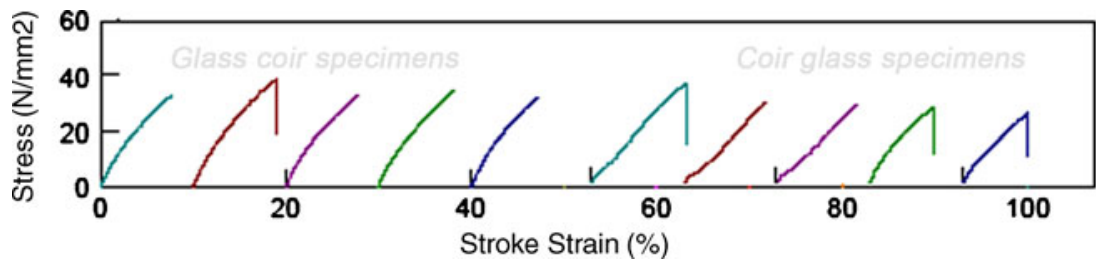

Figure 4. Stress-strain curve of 2-layered hybrid composites.

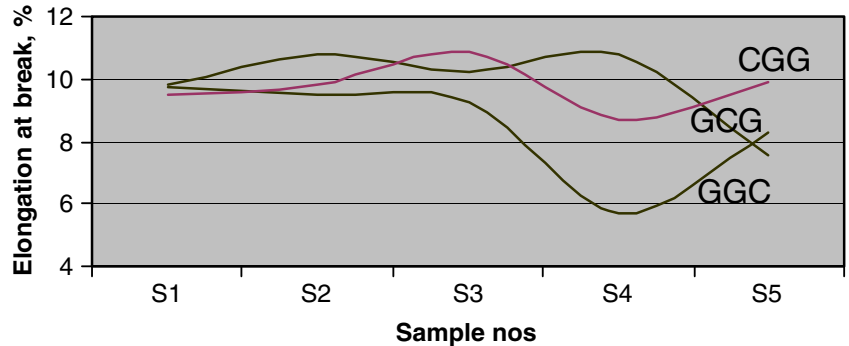

Figure 5. Elongation at break for different stacking sequences.

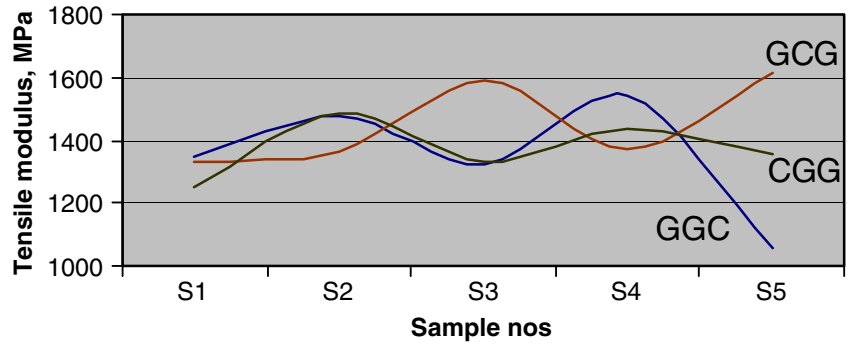

Figure 6. Tensile modulus of laminates.

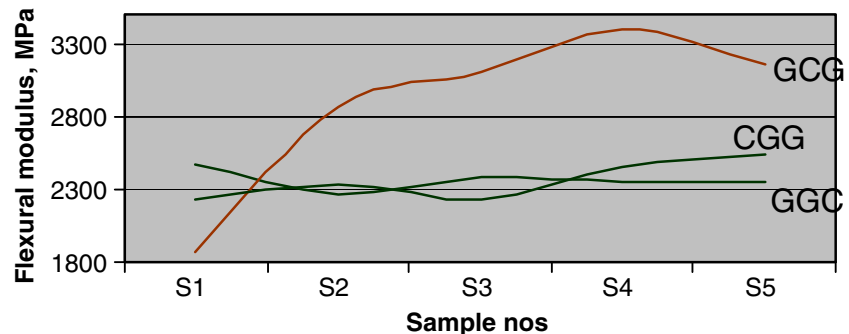

Figure 7. Flexural modulus of laminates.

ing, formation of fracture line, fibre pull out and fibre-resin compatibility were studied using SEM images. The observations revealed that the laceration was found on glass fibre due to the applied loads during tests. The formation of voids

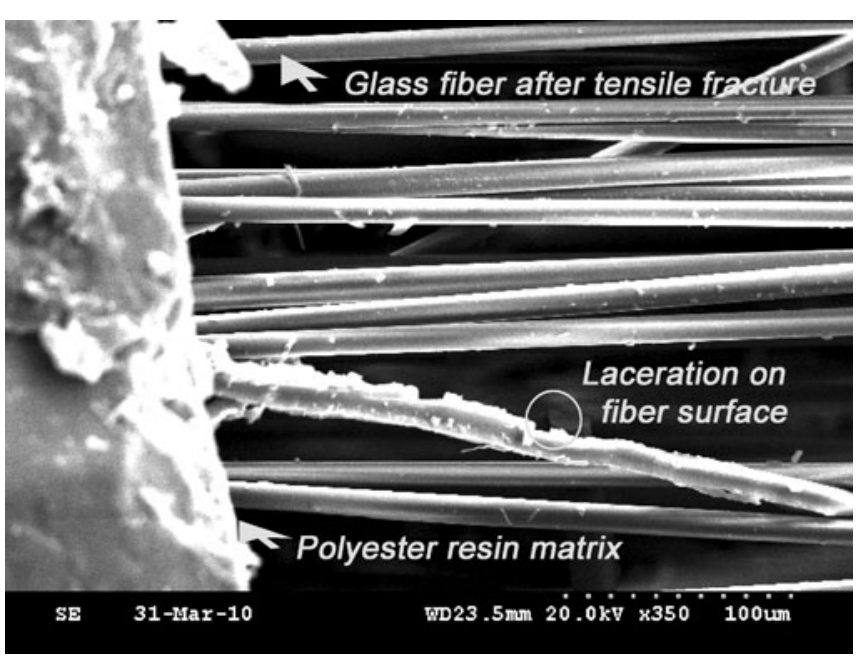

Figure 8. SEM image of glass-glass-coir specimens after tensile fracture.

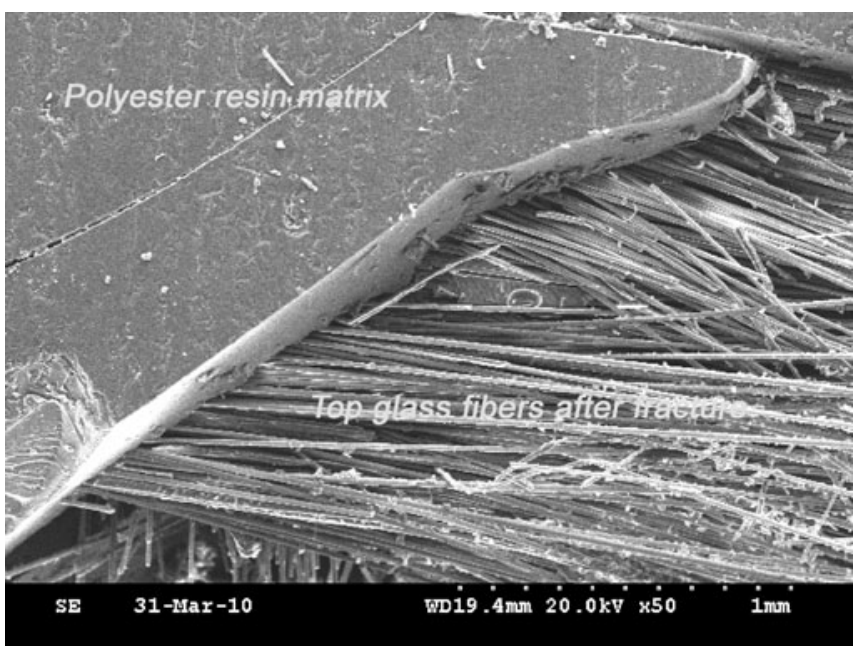

Figure 9. SEM image of glass-glass-coir specimens after tensile fracture from top.

due to fibre pull out was found in coir fibres because of poor resin compatibility of natural fibres. The matrix cracking and fracture lines were formed on the surfaces that exhibited poor interfacial bond. 


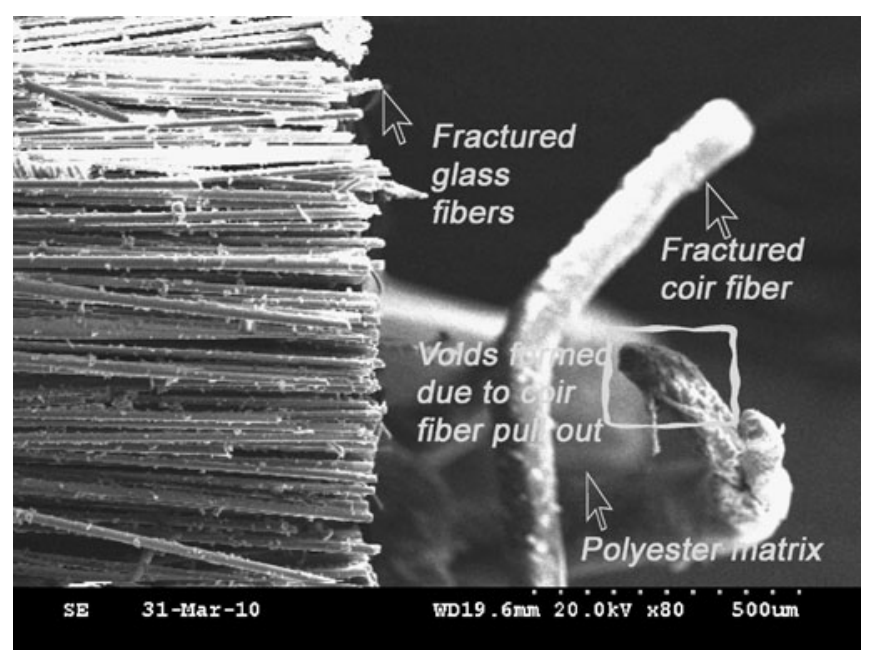

Figure 10. SEM image of glass-glass-coir specimens after flexural fracture.

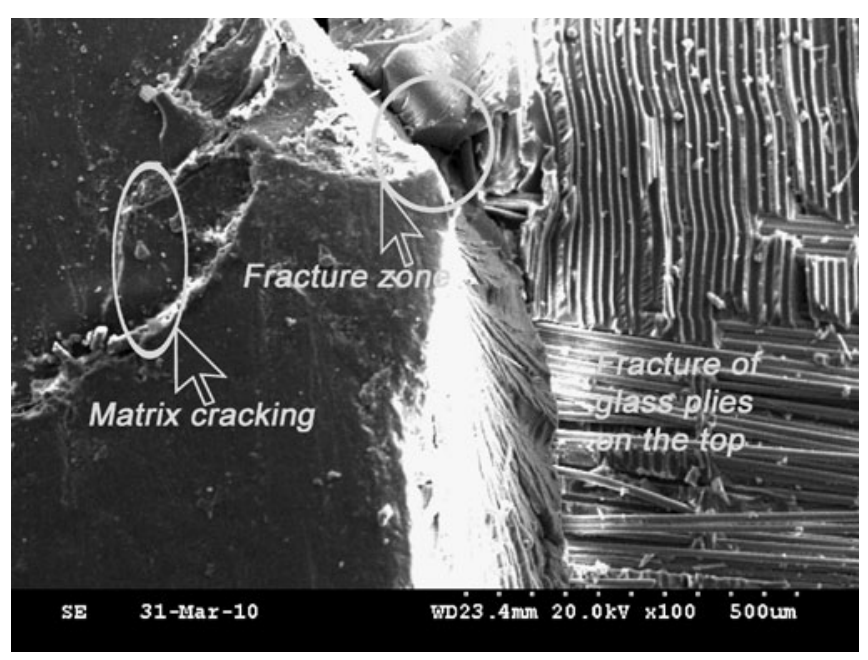

Figure 11. SEM image of glass-glass-coir specimens after impact fracture.

\section{Conclusions}

The highest value of tensile strength, flexural strength and impact strength were obtained for two-layer woven glass and single-layer woven coir fibres stacking sequence (GGC and $\mathrm{CGG}$ ). The mechanical properties of natural fibrewoven coir composites were significantly improved by glass hybridization. From the results of this study, the following conclusions were drawn:

(I) The two layers of woven glass at the extreme plies and coir mat (GGC) exhibited higher value of mechanical pro- perties, whereas the woven coir mat with two extreme woven glass plies (GCG) exhibited slightly less value of mechanical properties. The two layers of glass offered higher breaking resistance than the single layer above and below the woven coir mat in CGC specimen.

(II) The coir fibres fail quickly than the glass fibres. The two layers of glass plies at front (GGC) opposed the applied load greater than the two layers of glass plies at back (CGG) in woven coir-glass hybrid composites.

(III) Incorporation of woven glass in extreme plies of woven coir fibre composites enhances the improved mechanical properties of natural fibre composites.

(IV) Scanning electron micrographs showed that the fibre pull out started from natural fibres to glass fibres and good interfacial bond was developed between woven glass and polyester matrix rather than coir-polyester matrix.

Further research work needs to be carried out in the development of hybrid fibre-reinforced composites by the inclusion of filler material and fibre treatment for getting improved mechanical properties.

\section{Acknowledgements}

The authors would like to thank The Director, Central Institute of Plastics Engineering and Technology, Chennai, for providing the test facilities and the Development Officer, Coir Board, Pollachi, for providing the machinery set up for preparing woven coir mats.

\section{References}

Geethamma V G, Kalaprasad G, Groeninckx G and Thomas S 2005 Compos. Part A 361499

Harish S, Peter Michael D, Bensely A, Mohan Lal D and Rajadurai A 2009 Mater. Charact. 6044

Jarukumjorn K and Suppakarn N 2009 Compos. Part B 40623

Mallick P K 1993 Fibres reinforced composites-materials, manufacturing and design (New York: Marcel Dekker, Inc.) 2nd edn, pp. 243-244

Mishra S, Mohanty A K, Drzal L T, Misra M, Parija S, Nayak S K and Tripathy S S 2003 Compos. Sci. Technol. 631377

Monteiro S N, Terrones L A H and D'Almeida J R M 2008 Polym. Test. 27591

Noorunnisa Khanam P, Ramachandra Reddy G, Raghu K and Venkata Naidu S 2010 J. Reinf. Plast. Compos. 292124

Pavithran C, Mukherjee P C and Brahma Kumar M 1991 J. Reinf. Plast. Compos. 1091

Sabeel Ahmed K and Vijayarangan S 2008 J. Mater. Process. Technol. 207330

Venkata Subba Reddy E, Varada Rajulu A, Hemachandra Reddy K and Ramachandra Reddy G 2010 J. Reinf. Plast. Compos. 29 2119 